\title{
The Subgrade Improvement of the Road Construction with Geotextile Reinforcement on Kolaka Clay
}

\author{
$\operatorname{Irdhiani}{ }^{*}$, and Martini ${ }^{1}$ \\ ${ }^{1}$ Civil Engineering Department, Faculty of Engineering, Tadulako University, Palu, Indonesia
}

\begin{abstract}
Subgrade is an important part of road construction. Construction built on fine-grained subgrade such as clay is very susceptible to damage. The purpose of this study was to determine the CBR value with and without geotextile reinforcement as well as to know the effect of geotextile placement on CBR value. Soil material samples was from Kolaka Village, Mori Atas District, North Morowali Regency, Central Sulawesi Province and the geotextile material used was the Woven UW-150 type. Geotextile used for CBR testing was 2 reinforcement sheets with 6 variations of geotextile placement that are successively on each space 1 and 2, 1 and 3, 1 and 4, 2 and 3, 2 and 4 and 3 and 4 . The distance between spaces was $3 \mathrm{~cm}$. According to the Unified Classification System, soil samples were included in the $\mathrm{CH}$ group (non-organic clays with high plasticity, fat clays), and according to AASTHO was classified in the A-7-5 (53) group, that is clay. Compaction test resulted an optimum water content of $20.80 \%$ and maximum dry density of $1.54 \mathrm{gr} / \mathrm{cm}^{3}$. Laboratory CBR values without reinforcement at soaked and unsoaked conditions were respectively $4.61 \%$ and $9.68 \%$. The farther the distance between reinforcement as well as the farther the reinforcement distance to the ground surface, the greater the CBR value gained.
\end{abstract}

\section{Introduction}

The Kolaka-Wawopada road section is part of Trans Sulawesi Road, where this road section is the only road connecting Poso Regency and Morowali Utara Regency. This road section has such typical soil structure characteristic, so the development planning requires in-depth study. The road was paved in the 1990s and is now completely damaged. Even though this road has been repeatedly repaired with high costs, the condition has always been badly damaged in under a year. This is likely due to the highwater content and the soft coal contained in the soil.

\footnotetext{
*Corresponding author: irdhiani@yahoo.co.id
} 
The subgrade improvement can be done in several ways, one of which is by providing layer of reinforcement in the form of geotextiles on the road. Geotextile is a reinforcement sheet used in this study to improve subgrade bearing capacity showed by an increase of CBR value, so that to meet the standard CBR value of subgrade for road construction. The type of geotextile used in this study is woven geotextile as this material has high tensile strength, superior long-term performance, high resistance and is easy to apply.

\section{Literature Review}

\subsection{Soil Classification system}

\subsubsection{Unified Soil Classification System, USCS}

The USCS divides soil into 2 categories: coarse-grained soil (gravel and sand) if 50\% or less passes sieve number 200, and fine-grained soil (silt / clay) if more than $50 \%$ passes sieve number 200. This classification uses the symbol for each group with 2 letters. The first letter states the dominant type of soil and the second letter states the quality of the soil, level of plasticity or type of soil contained in the dominant soil.

\subsubsection{American Association of State Highway and Transporting Official Classification System, AASHTO}

The AASHTO classification system is used to determine soil quality for road subbase and subgrade. Granular soil is classified into A-1 to A-3. A-1 is well graded soil, while A-3 is poorly graded clean sand. A-2 is granular soil (less than 35\% passes sieve number 200), but still contains silt and clay. Fine-grained soils are classified from A-4 to A-7, which is silt clay. The difference between the two is based on its Atterberg limits.

\subsection{Activities}

Amount and type of clay minerals contained in soil will affect the liquid and plastic limit of soil. Skempton investigated the correlation between plasticity index (PI) of a soil and clay percentage contained [1]. He also found that the plasticity index (PI) is increased in accordance with the increasing percentage of clay contained in the soil. The activity of clay is used as an index to identify soil's ability to expand. The activity value defined by Skempton is as follows:

$$
A=\frac{P I}{(\text { weight of fraction sized } 0,02(\%))}
$$

\subsection{Compaction}

Compaction is a process in which soil consisting of soil grains, water, and air is given compaction energy with the aim of removing air in the soil pores so that the soil volume will decrease. Field compaction can be done in various ways, one of them is by crossing over the 
ground using soil compaction equipment's such as sheepsfoot roller. Laboratory compaction can be done by using the Standard Compaction Test and Modified Compaction Test methods.

The purpose of compaction test is to reduce compressibility and permeability of soil and to determine the value of water content at the maximum dry weight. This value is called the optimum water content, obtained from the compaction test results and used for CBR testing. There are three factors that influence soil compaction [2]:

1. Water content

2. Soil classification (gradation, cohesive or non-cohesive, grain size, etc.)

3. Compaction energy

\subsection{California Bearing Ratio (CBR)}

CBR value is one of the parameters used to determine bearing capacity of subgrade in designing road pavement. If the subgrade has high CBR value, it will practically reduce the thickness of the pavement layers which are above the subgrade, and vice versa. The method originally created by O.J. Porter, which was later developed by the California State Highway Department and modified by the United States Army Corps of Engineers). CBR is the comparison of test load to standard load and expressed as percentage [3].

$$
C B R=\frac{P_{T}}{P_{S}} \times 100 \%
$$

where:

$P_{T}=$ corrected test load corresponding to the chosen penetration from the load penetration curve

$P_{S}=$ standard load for the same penetration

$$
\begin{aligned}
& C B R 0,1^{\prime \prime}=\frac{P_{1}}{3000} \times 100 \% \\
& C B R 0,2^{\prime \prime}=\frac{P_{2}}{4500} \times 100 \%
\end{aligned}
$$

Where $P_{1}$ and $P_{2}$ are load dial readings in CBR testing. CBR test is conducted after the soil has been compacted.

\subsection{Geotextile}

Geotextiles are sheet-shaped products made from flexible polymer materials used mutually with soil, rocks, or other geotechnical minerals as an inseparable part of a structure or system [4].

Based on its type, geotextile is divided into 2 type, non-woven and woven geotextiles. Woven geotextile is made of polypropylene base material for easy application. Woven geotextile has higher tensile strength compared to non-woven geotextile, which is about 2 times with the same weight per $\mathrm{m}^{2}$. Woven geotextiles functions as a stabilizing material for subgrade, especially soft subgrade so that it can be coated and the surface will not easily be degraded. Geotextile is not resistant to sunlight, since the sun contains ultraviolet rays which cause rapid degradation [5].

\section{Research Method}




\subsection{Research Stages}

This research is an experimental study. The stages of the research can be seen in the following flow chart:

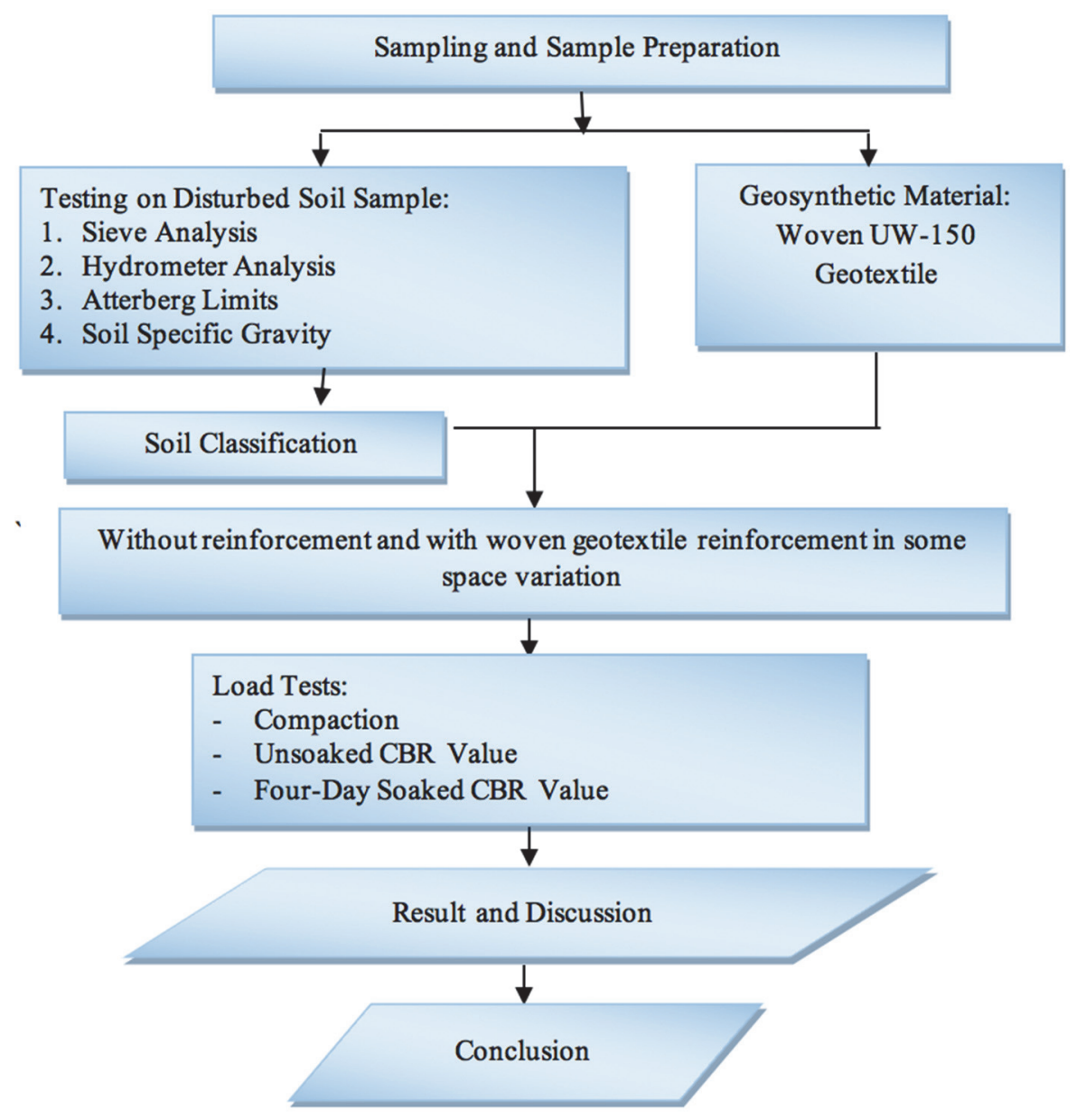

Fig. 1. Research Flow Chart

\subsection{Laboratory Tests}

The data needed in this study are obtained from laboratory, including test of mechanical and physical properties. Tests of physical properties conducted in this study are: Sieve Analysis, Hydrometer Analysis, Atterberg Limits and Soil Specific Gravity. Mechanical properties tests are: Modified Proctor Compaction Test and California Bearing Ratio Test (CBR). 


\subsection{Geotextile Installation}

The height of the mould used in this installation was $15 \mathrm{~cm}$ and the amount of layer for compaction was five layers with the same height. Reinforcement placement on CBR testing can be seen in Figure 2.

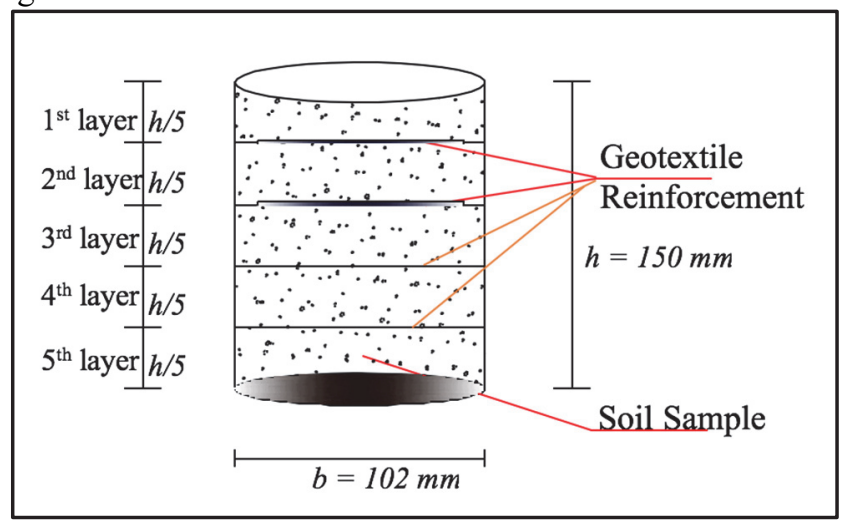

Fig. 2. Placement of Reinforcement on CBR Test

Geosynthetic reinforcement used is Geotextile UV-150 Woven with thickness of $0.5 \mathrm{~mm}$, has the weight of $150 \mathrm{gr} / \mathrm{m}^{2}$, and tensile strength of $35 \mathrm{kN} / \mathrm{m}$.

The reinforcement used for CBR test was 2 sheets of geotextile reinforcement with five variation of placements which are variation $\mathrm{A}, \mathrm{B}, \mathrm{C}, \mathrm{D}, \mathrm{E}$, and $\mathrm{F}$. The variation of geotextile placement for each space was respectively space 1 and 2, 1 and 3, 1 and 4, 2 and 3, 2 and 4 and 3 and 4. Variations in geotextile reinforcement placement can be seen in Figure 3.

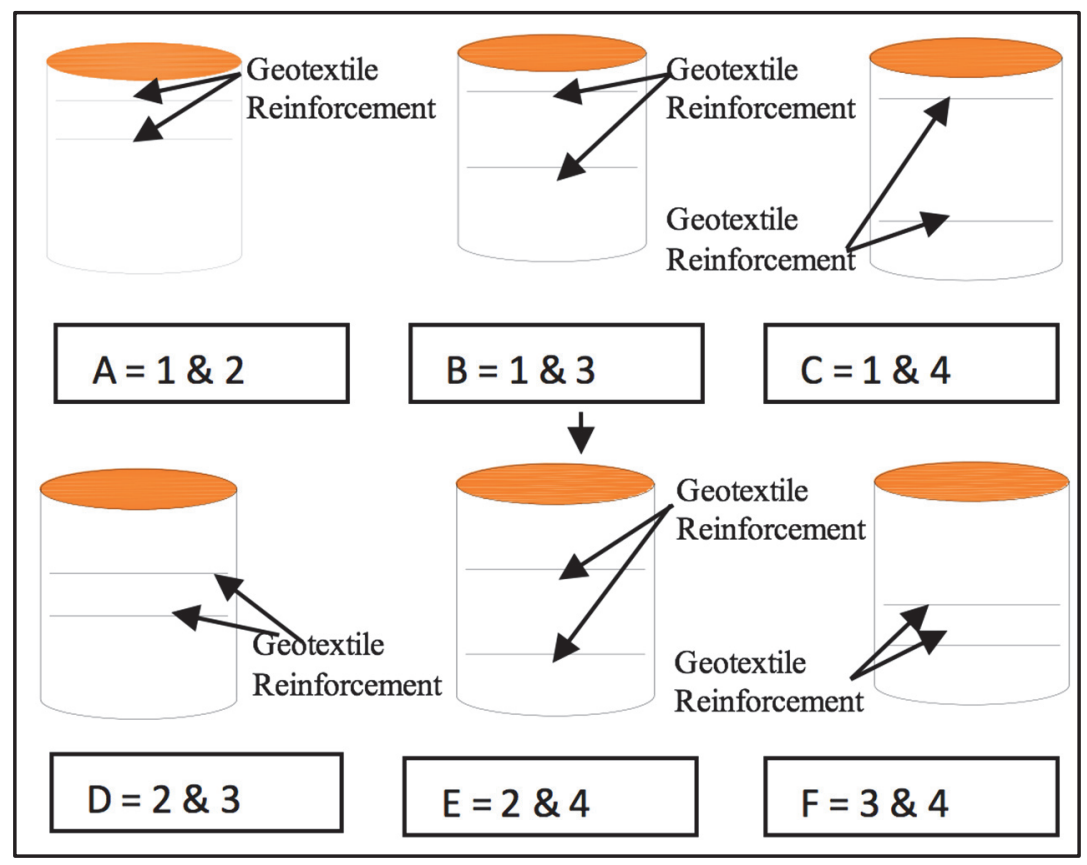

Fig. 3. Placement Variations with Geotextile Reinforcemen 


\section{Result and Discussion}

\subsection{Physical Properties of Kolaka Clay Soils}

The results of soil physical properties test conducted in laboratory can be seen in Table 1 below:

Table 1. Result of Soil Physical Properties Test

\begin{tabular}{|c|c|c|}
\hline Parameters & Unit & Result \\
\hline Percent passing sieve No. 200 & $\%$ & 96,87 \\
Sand (0,074-5 mm) & $\%$ & 3,14 \\
Silt (0,002-0,074 mm) & $\%$ & 40,99 \\
Clay (<0,002 mm) & $\%$ & 55,87 \\
\hline Liquid Limit (LL) & $\%$ & 80,16 \\
Plastic Limit (PL) & $\%$ & 35,72 \\
Plasticity Index (PI) & $\%$ & 44,44 \\
\hline Specific Gravity & & 2,60 \\
\hline
\end{tabular}

Percentage of soil that passed sieve No. 200 was $96.87 \%$. It shows that soil was finegrained soil based on both AASHTO classification system and the USCS classification system. Atterberg limits test result show that the value of liquid limit (LL), plastic limit (PL) and plasticity index (PI) respectively $80.16 \%, 35.72 \%$ and $44.44 \%$. According to the AASHTO classification, soil sample were classified as A-7-5 (53), and according to USCS classification, it was classified as $\mathrm{CH}$.

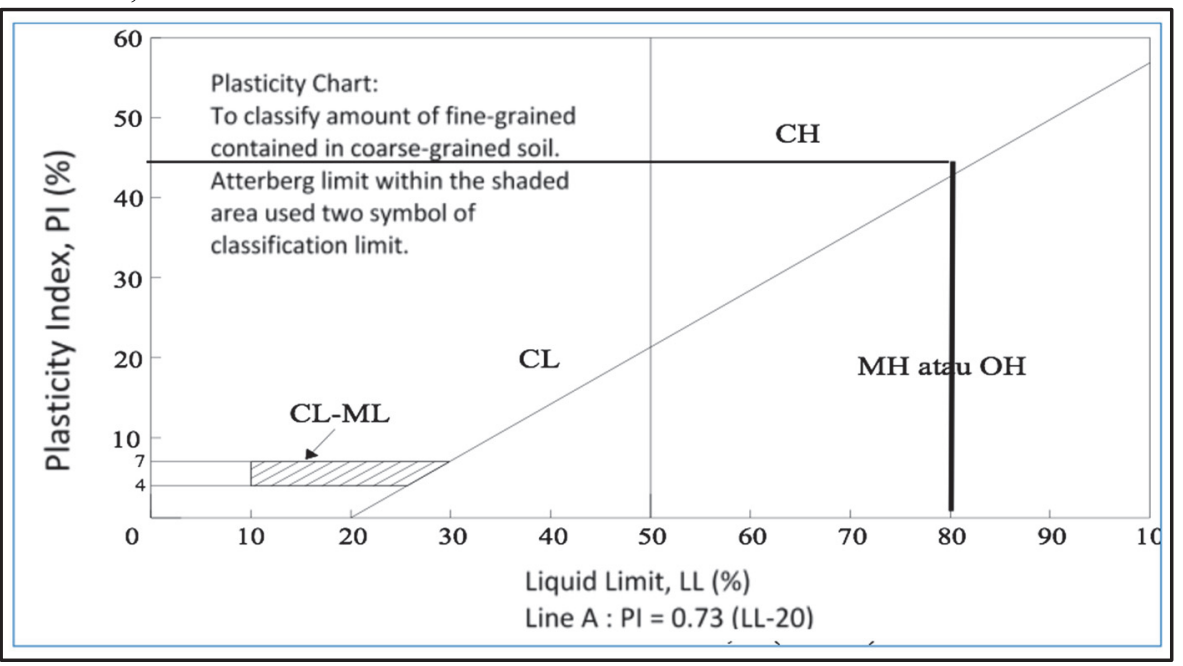

Fig. 4. Plasticity Chart 
Soil samples had $55.87 \%$ of fraction sized $2 \mu$ and plasticity index of $44.44 \%$. The activity value (A) obtained was 0.80 . Based on the activity value, the clay mineral contained in the soil sample was illite.

\subsection{Mechanical Properties}

The compaction experiment used the modified compaction method with 5 soil samples in which the water content was varied to form a graph showing the relation between dry density and water content. The optimum water content obtained from the graph was $20.80 \%$ and the maximum dry density was $1.54 \mathrm{gr} / \mathrm{cm}^{3}$. Soil can experience maximum compaction if the water content given to the soil is sufficient enough to improve its technical properties: dry unit weight. However, if given an excessive amount of water, the stability of the soil will be decreased.

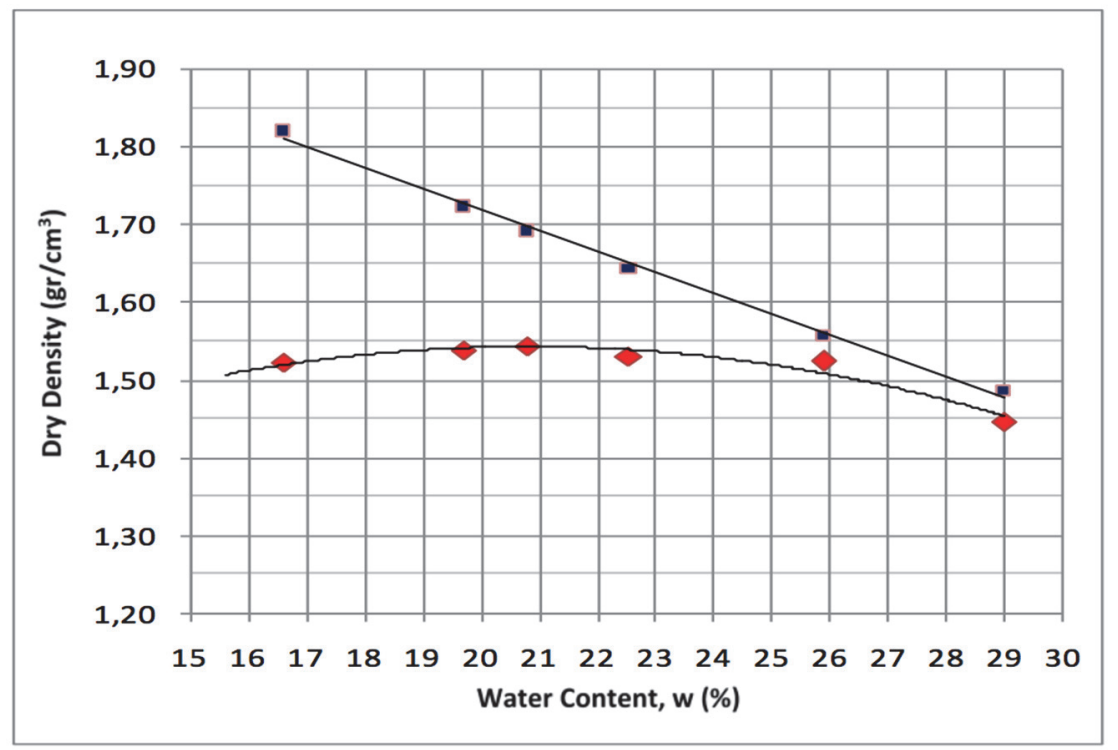

Fig. 5. Result of Modified Compaction Test

\subsubsection{Unsoaked CBR}

Unsoaked CBR test was conducted to the soil sample that had no geotextile reinforcement and to the sample using geotextile reinforcement with varied spacing between each reinforcement. The height of mould used in the test was $15 \mathrm{~cm}$ with 5 layers of compacted soil with the same height. The total of reinforcement sheet used was two sheets with 6 variations of the reinforcement placement: space 1 and 2, 1 and 3,1 and 4,2 and 3, 2 and 4 and 3 and 4.

The CBR test result at penetration of 0.1 "and 0.2 " for unreinforced and reinforced sample can be seen in Table 2 and Figure 6.

Table 2. Result of Unsoaked CBR Test 


\begin{tabular}{|c|c|c|c|c|c|c|c|}
\hline \multirow{2}{*}{$\begin{array}{c}\text { Number of } \\
\text { Reinfor- } \\
\text { cement }\end{array}$} & \multirow{2}{*}{$\begin{array}{c}\text { Varia- } \\
\text { tion }\end{array}$} & \multicolumn{2}{|c|}{$\begin{array}{l}\text { CBR Value at } 0.1 \\
\text { Penetration (\%) }\end{array}$} & \multirow{2}{*}{$\begin{array}{c}\text { Average } \\
\text { Value at } 0.1 \\
\text { Penetration } \\
\quad(\%)\end{array}$} & \multicolumn{2}{|c|}{$\begin{array}{l}\text { CBR Value at } 0.2 \\
\text { Penetration (\%) }\end{array}$} & \multirow{2}{*}{$\begin{array}{c}\text { Average } \\
\text { Value at } 0.2 \\
\text { Penetration } \\
(\%)\end{array}$} \\
\hline & & Sample 1 & Sample 2 & & Sample 1 & Sample 2 & \\
\hline 0 & - & 7,61 & 7,90 & 7,76 & 9,59 & 9,77 & 9,68 \\
\hline \multirow{6}{*}{2 sheets } & $\mathrm{A}$ & 16,36 & 16,50 & 16,43 & 17,38 & 16,91 & 17,43 \\
\hline & B & 17,62 & 17,76 & 17,76 & 18,79 & 18,98 & 18,89 \\
\hline & $\mathrm{C}$ & 18,75 & 18,89 & 18,82 & 19,83 & 19,92 & 19,87 \\
\hline & $\mathrm{D}$ & 19,03 & 19,17 & 19,10 & 20,01 & 20,11 & 20,06 \\
\hline & $E$ & 19,31 & 19,45 & 19,38 & 20,20 & 20,30 & 20,25 \\
\hline & $\mathrm{F}$ & 19,59 & 19,73 & 19,66 & 20,30 & 20,48 & 20,39 \\
\hline
\end{tabular}

The CBR value without reinforcement is eligible to be used as subgrade for road pavement because the CBR value obtained was greater than $6 \%$ and the CBR value of the sample using 2 reinforcement sheets has increased significantly.

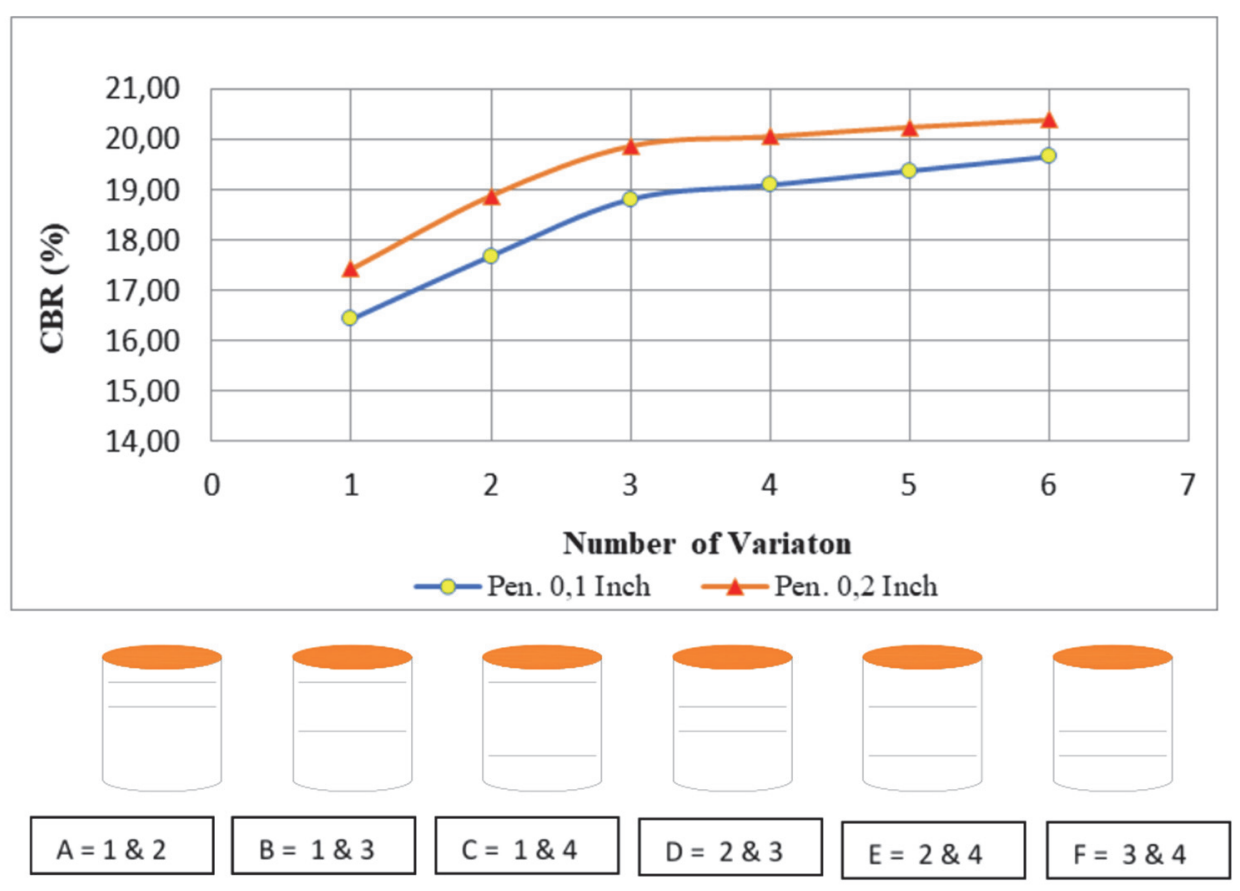

Fig. 6. Graph of Unsoaked CBR Value with Two Reinforcement Sheets

CBR values obtained from variation A, B, C, D, E, and F had dry density at constant optimum water content. It showed that the soil can resist the CBR piston to a certain extent, resulting in the high $\mathrm{CBR}$ value. Figure 6 shows that the $\mathrm{CBR}$ value increases if the distance between spaces increases. This can be seen in variation A, B and C, as well as variation D 
and $\mathrm{E}$. The highest $\mathrm{CBR}$ value obtained at the farthest reinforcement distance from the ground surface that is variation $\mathrm{F}$.

\subsubsection{Soaked CBR}

1. CBR value without reinforcement

Soaked CBR variation test without reinforcement resulted an average CBR value of $3.81 \%$ at 0.1 "penetration, while the average CBR value at 0.2 " penetration was $4.61 \%$. The result of soaked CBR test that simulate flood condition produced a value of less than $6 \%$. This CBR value was obtained because the clay was soaked in the water that it significantly expanded and resulted in the loss of the bearing capacity.

2. CBR Value of Two Reinforcement Sheets Sample

CBR variation test with two reinforcement sheets at soaked state was consisted of 6 variations of reinforcement placement and the same space variation as unsoaked CBR test. Result of CBR test with 2 reinforcement sheets can be seen in Table 3 and Figure 7.

Table 3. Result of Soaked CBR Test

\begin{tabular}{|c|c|c|c|c|c|c|c|}
\hline \multirow{2}{*}{$\begin{array}{c}\text { Number } \\
\text { of } \\
\text { Reinfor- } \\
\text { cement }\end{array}$} & \multirow{2}{*}{$\begin{array}{c}\text { Varia- } \\
\text { tion }\end{array}$} & \multicolumn{2}{|c|}{$\begin{array}{l}\text { CBR Value at } 0.1 \\
\text { Penetration (\%) }\end{array}$} & \multirow{2}{*}{$\begin{array}{c}\text { Average } \\
\text { Value at } 0.1 \\
\text { Penetration } \\
(\%)\end{array}$} & \multicolumn{2}{|c|}{$\begin{array}{l}\text { CBR Value at } 0.2 \\
\text { Penetration (\%) }\end{array}$} & \multirow{2}{*}{$\begin{array}{c}\text { Average } \\
\text { Value at } 0.2 \\
\text { Penetration } \\
(\%)\end{array}$} \\
\hline & & Sample 1 & Sample 2 & & Sample 1 & Sample 2 & \\
\hline 0 & - & 3,95 & 3,67 & 3,81 & 4,70 & 4,51 & 4,61 \\
\hline \multirow{6}{*}{2 Sheets } & A & 4,79 & 4,93 & 4,86 & 5,63 & 5,82 & 5,73 \\
\hline & B & 5,58 & 5,76 & 5,67 & 6,57 & 6,76 & 6,67 \\
\hline & $\mathrm{C}$ & 6,23 & 6,72 & 6,47 & 7,39 & 7,50 & 7,44 \\
\hline & $\mathrm{D}$ & 6,94 & 7,19 & 7,06 & 7,89 & 7,98 & 7,94 \\
\hline & $\mathrm{E}$ & 7,33 & 7,47 & 7,40 & 8,08 & 8,17 & 8,13 \\
\hline & $\mathrm{F}$ & 7,61 & 7,75 & 7,68 & 8,27 & 8,36 & 8,31 \\
\hline
\end{tabular}

The test result shows that the CBR value increased as the spacing between each reinforcement and reinforcement distance to ground surface increased. The highest CBR value, $8.31 \%$, was found at variation $\mathrm{F}$ where the distance of reinforcement to the ground surface was the farthest. The lowest CBR value, 5.73\%, was found at variation A where the distance of reinforcement to the ground surface was the closest.

The average CBR value of reinforced soaked sample in variation A and $B$, did not meet the qualification of the road pavement subgrade due to the obtained CBR value that is less than $6 \%$.

Variation A, B and C had the same reinforcement distance to the ground surface yet showed different CBR values. It occurred because the distance between reinforcement (spaces) was different, the farther the distance the higher the CBR value would be. At 0.2 " penetration, variation A had unsoaked CBR value of 17.43 and soaked CBR value of 5.73, variation $B$ had unsoaked $C B R$ value of 18.89 and soaked $C B R$ value of 6.67 , and variation $\mathrm{C}$ had unsoaked CBR value of 19.87 and soaked CBR value of 7.44. This is shows that 
reinforcement spacing affects the value of CBR, the farther the reinforcement spacing, the higher the CBR value would be. This occurred because the volume of soil above the reinforcement layer acted as the load to the layer, resulted to a bigger friction so that the soil under the reinforcement layer was relatively denser and caused higher CBR values.

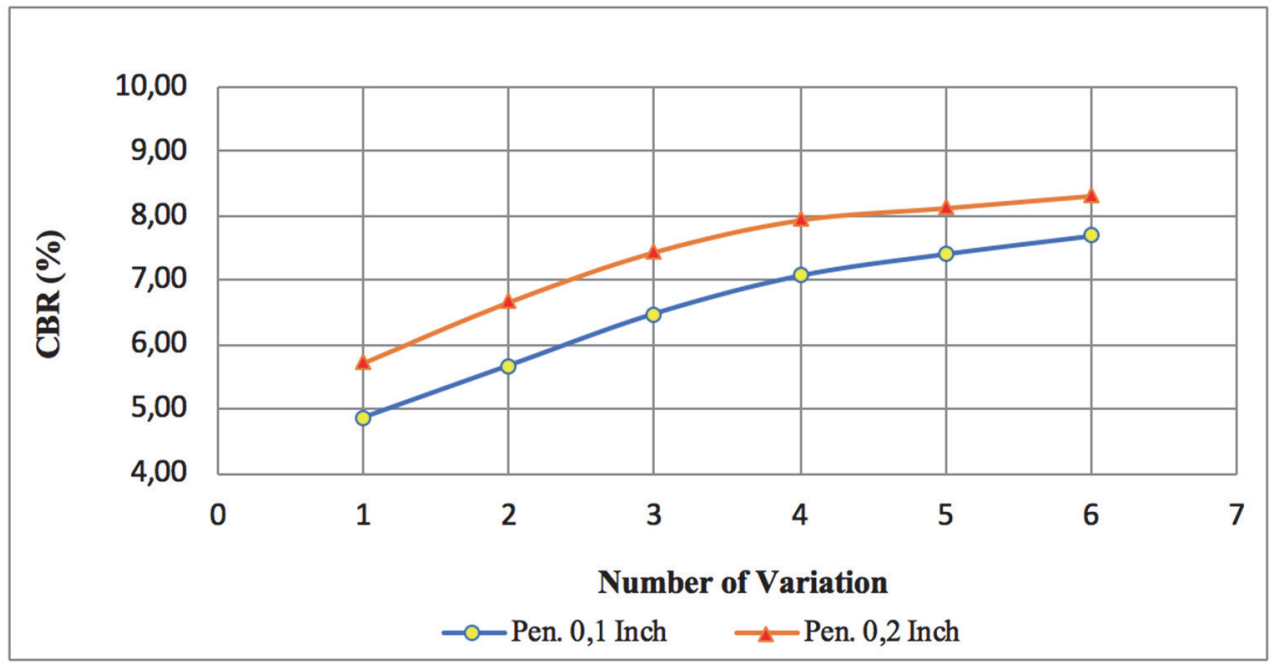

Fig. 7. Graph of Soaked CBR Value with Two Reinforcement Sheets

Whereas for the same reinforcement space as in variation A, D and F, showed different CBR values, this was because each variation had different reinforcement distance to the ground surface. The farther the reinforcement distance from the ground surface, the higher the CBR value. At 0.2 " penetration, variation A had unsoaked CBR value of 17.43 and soaked CBR value of 5.73, variation D had unsoaked CBR value of 20.06 and soaked CBR value of 7.94, and variation $F$ had unsoaked CBR value of 20.39 and soaked CBR value of 8.31. This also showed that the reinforcement distance to the ground surface affected the CBR value, the closer the reinforcement to the ground surface, the lower the CBR value, as the soil volume above the reinforcement layer was decreasing, resulted to a small bearing capacity value, similarly to variation $B$ and $E$.

\section{Conclusion}

The results of this study can be concluded as follows:

1. CBR value without reinforcement at unsoaked condition is $9.68 \%$ and soaked condition is $4.61 \%$. The unsoaked CBR value with reinforcement is eligible to be used as road pavement subgrade while soaked CBR value with reinforcement space of 1 and 2, 1 and 3 is not eligible for subgrade due to the CBR value which is less than $6 \%$.

2. Soil sample with reinforcement both at soaked and unsoaked conditions had increased CBR value when the space between each reinforcement and reinforcement distance to the ground surface increased. The highest CBR value was found in variation $\mathrm{F}$, as it has the farthest reinforcement distance to the ground surface and the space of 3 and 4 . The unsoaked CBR value is $20.39 \%$ and the soaked one is $8.31 \%$. Whereas the lowest CBR value was found in variation $\mathrm{A}$, as it has the closest reinforcement distance to the ground 
surface as well as the space distance, which is space 1 and 2 . The unsoaked CBR value is $17.43 \%$ and the soaked one is $5.73 \%$.

3. The spacing between reinforcement sheet affected the CBR value. The farther the distance between reinforcement the greater the CBR value will be, as well as the distance of the reinforcement distance to the ground surface, the farther the reinforcement distance to the ground surface the greater the CBR value will be. This is because the more volume of soil acted above reinforcement sheet, the greater the friction that causes soil beneath the reinforcement layer to be more relatively dense.

\section{References}

1. Das, B. M. (1998). Mekanika Tanah (Prinsip-Prinsip rekayasa Geoteknis) Jilid 1. (N. Endah\&I. B. Mochtar, Trans). Jakarta: Erlangga (Original work published 1988).

2. Hardiyatmo, H. C. (2012). Mekanika Tanah 1 Edisi ke Enam. Yogyakarta: Gadjah Mada University Press.

3. Soedarmo, G. D. \& Purnomo, S. J. (1993). Mekanika Tanah 1. Malang: Kanisus.

4. Direktorat Bina Teknik. (2009). Modul Pelatihan Geosintetik Volume 1 (Klasifikasi dan fungsi Geosintetik). Jakarta: Kementrian Pekerjaan Umum.

5. Hardiyatmo, H. C. (2013). Geosintetik Untuk Rekayasa Jalan Raya (Aplikasi dan Perancangan). Yogyakarta: Gadjah Mada University Press. 